\title{
UPDATING ON DIAGNOSIS AND TREATMENT OF CHONDRAL LESION OF THE KNEE
}

Marcantonio Machado da Cunha Cavalcanti Filho', Daniel Doca², Moisés Cohen ${ }^{3}$, Mário Ferretti ${ }^{4}$

\section{ABSTRACTS}

The treatment of chondral knee injuries remains a challenge for the orthopedic surgeon, mainly owing to the characteristics of the cartilage tissue, which promote low potential for regeneration. Chondral lesions can be caused by metabolic stimulation, or by genetic, vascular and traumatic events, and are classified according to the size and thickness of the affected cartilage. Clinical diagnosis can be difficult, especially due to insidious symptoms. Additional tests, as Magnetic Resonance Imaging (MRI), may be needed. The treatment of these lesions usually starts with non-operative management. Surgery should be reserved for patients with detached chondral fragments, blocked range of motion, or the failure of non-operative treatment. The surgical techniques used for the treatment of partial thickness defects are Debridement and Ablation. These techniques aim to improve symptoms, since they do not restore normal structure and function of the cartilage. For full-thickness defects (osteochondral lesion), available treatments are Abrasion, Drilling, Microfracture, Osteochondral Autologous and Allogeneic Transplantation, and biological techniques such as the use of Autologous Chondrocyte Transplantation, Minced Cartilage and stem cells.

Keywords - Cartilage Diseases; Knee; Arthroscopy; Articular Cartilage

\section{INTRODUCTION}

The knee is a diarthrodial joint formed by two joint surfaces: the tibiofemoral and patellofemoral surfaces. The medial and lateral tibiofemoral compartments, together with the patellofemoral joint, form the three compartment of the knee, and these are covered by hyaline joint cartilage ${ }^{(1)}$.

Hyaline joint cartilage is a kind of dense conjunctive tissue consisting of cells, water and matrix. The tissue is well-structured and elastic, with a smooth white surface. The main functions of joint cartilage are to protect the subchondral bone, allow the contact surfaces to slide across each other without friction and absorb impact ${ }^{(2-5)}$.

Hyaline cartilage is composed mainly of chondrocytes surrounded by an extracellular matrix ${ }^{(3-6)}$. This matrix is synthesized and secreted by the chondro- cytes and is composed mainly by type II collagen fibers, proteoglycans and water ${ }^{(4,6)}$. Morphologically, hyaline cartilage has four layers: superficial, intermediate, deep and calcified layers ${ }^{(3)}$. The biomechanical properties of the joint cartilage are largely dependent on the composition and integrity of the extracellular matrix. Joint cartilage tissue is hypocellular, avascular, aneural and non-lymphatic, which diminishes the possibility of tissue regeneration ${ }^{(3,6)}$.

Chondral lesions are caused through degradation of joint cartilage, in response to metabolic, genetic, vascular and traumatic stimuli. They can occur because of a single episode of overload on the knee joint, or through several cyclical episodes of small magnitude. These lesions are subdivided according to the cartilage thickness affected, and go from microlesions and chondral lesions to osteochondral lesions

1. Intern of the Locomotor Program of the Hospital Israelita Albert Einstein (HIAE) - São Paulo, SP, Brazil.

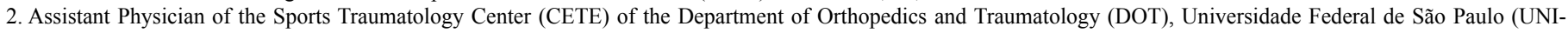
FESP) - São Paulo, SP, Brazil.

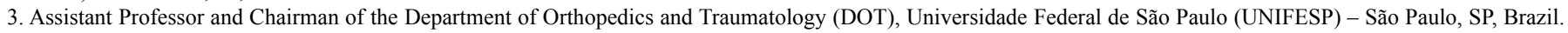

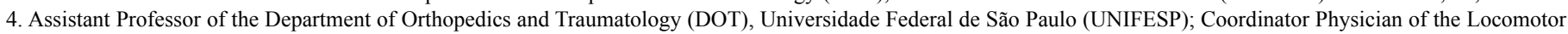
Program of the Hospital Israelita Albert Einstein (HIAE) - São Paulo, SP, Brazil.

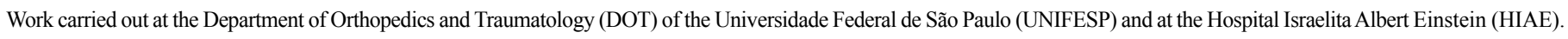
Correspondence: Mário Ferretti Rua Borges Lagoa n 783, $5^{\circ}$ Andar Vila Clementino São Paulo - Cep: 04038-32 E-mail: ferretti@einstein.br

Received for publication: 08/04/2011, accepted for publication: 09/24/2011

The authors declare that there was no conflict of interest in conducting this work 
that involve all layers of the joint cartilage and affect the subchondral bone ${ }^{(7)}$.

Osteochondral lesions in patients with healthy cartilage generally have a traumatic origin. Although some chondral lesions are asymptomatic, they may evolve with cartilage degeneration and osteoarthrosis ${ }^{(8)}$.

\section{Classification of chondral lesions}

Joint cartilage defects are differentiated into two categories: defects of partial thickness and those of full thickness (osteochondral defects) ${ }^{(5)}$.

In 1961, Outerbridge ${ }^{(9)}$ classified macroscopic joint cartilage abnormalities into four grades: grade I, softening of the cartilage; grade II, fragmentation and fissuring over an area of half an inch in diameter or less (1.5 $\mathrm{cm}$ in diameter or less); grade III, this process increases to involve an area greater than half an inch in diameter (greater than $1.5 \mathrm{~cm}$ in diameter); and grade IV, a lesion compromising the entire thickness of the cartilage, with exposure of the subchondral bone.

The International Cartilage Repair Society (ICRS) system for evaluating cartilage repairs was developed from the work by Brittberg et $\mathrm{al}^{(10)}$. The scoring system for macroscopically assessing cartilage defect repairs was then described more comprehensively by Peterson et $\mathrm{al}^{(11)}$. This classification was adopted and simplified by the ICRS and has been used for assessing the grades of chondral lesions $^{(12)}$ (Table 1).

Table 1 - Classification of chondral lesions according to the ICRS system.

\begin{tabular}{|c|c|}
\hline Normal & Grade 0 \\
\hline Almost normal & $\begin{array}{l}\text { Grade } 1 \mathrm{a} \text { - superficial lesions/softening } \\
\text { Grade } 1 \mathrm{~b}-\text { As in } 1 \mathrm{a} \text { and/or superficial fissures or } \\
\text { cracks }\end{array}$ \\
\hline Abnormal & Grade $2-$ extent $<50 \%$ of thickness \\
\hline Severe lesion & $\begin{array}{l}\text { Grade } 3 a-\text { extent }>50 \% \\
\text { Grade } 3 b-\text { down to the calcified layer } \\
\text { Grade } 3 c-\text { down to the surface of the subchondral } \\
\text { bone (without penetration) } \\
\text { Grade } 3 d-\text { includes bulging of the cartilage around } \\
\text { the lesion }\end{array}$ \\
\hline $\begin{array}{l}\text { Very severe } \\
\text { lesion }\end{array}$ & $\begin{array}{l}\text { Grade } 4 a-\text { penetration of the subchondral bone } \\
\text { but not across the entire diameter of the defect } \\
\text { Grade } 4 b-\text { penetration across the full diameter of } \\
\text { the defect }\end{array}$ \\
\hline
\end{tabular}

\section{Epidemiology}

The real incidence of osteochondral lesions in humans is unknown, because a large proportion of them are asymptomatic. In an attempt to estimate their incidence, two large studies were conducted retrospectively ${ }^{(13,14)}$.

In the study by Curl et $\mathrm{al}^{(13)}$, it was observed that $41 \%$ of the patients with chondral lesions that were detected during arthroscopy presented fragmentation and fissuring over an area greater than half an inch in diameter (grade III Outerbridge chondral lesions) and $19.2 \%$ presented cartilage erosion involving subchondral bone (grade IV Outerbridge chondral lesions). According to this study, $20 \%$ of the chondral lesions classified as grade IV are located in the medial femoral condyle, and $72 \%$ of the cases of grade IV chondral lesions are found in patients over the age of 40 years.

In the study by Widuchowski et al ${ }^{(14)}$, some type of chondral lesion was found in $60 \%$ of the knees operated, of which $67 \%$ were classified as osteochondral or chondral lesions, $29 \%$ as osteoarthritis, $2 \%$ as osteochondritis dissecans and $1 \%$ as other types. Lesions that were not limited to the cartilage occurred in $70 \%$ of the cases, while lesion thus limited accounted for $30 \%$. The most frequent locations were the joint surface of the patella (36\%) and the medial femoral condyle (34\%). Lesions classified as grade II according to Outerbridge were the most frequent type, occurring in $42 \%$ of the cases. The type of lesion most commonly associated with chondral lesions was tearing of the medial meniscus, in $42 \%$, followed by lesions of the anterior cruciate ligament, in $36 \%$.

\section{DIAGNOSIS}

Clinical - The clinical diagnosis may be difficult to make, since the symptoms are poor. The most frequent complaints are pain, joint effusion, lockage and crepitation. The symptoms are generally insidious, with diffuse or specific pain at the joint interline and in the anterior region of the knee ${ }^{(7)}$. Some provocative tests can be performed to diagnose the lesion, such as the Wilson test, which identifies osteochondritis dissecans in the medial condyle ${ }^{(15)}$.

Radiological (X-ray) - The radiological diagnosis may be important for ruling out other pathological conditions and associated lesions, such as degenerative lesions (presence of osteophytes, cysts, subchondral sclerosis and joint space reduction) ${ }^{(16)}$ and fractures. It may also make it possible to view complete chondral lesions with loose fragments in the 
joint cavity, i.e. the pathological condition known as osteochondritis dissecans.

Tomography and arthrotomography - These basically have the same diagnostic indications as radiography, and injection of intra-articular contrast (arthrotomography) directly demonstrates the presence of chondral lesions. With the advent of nuclear magnetic resonance, this examination is no longer considered to be the gold standard. Moreover, there are risks involved in injecting contrast into the joint.

Nuclear magnetic resonance (NMR) - Magnetic resonance, with its excellent contrast in soft tissue, is the best imaging technique available for studying cartilage lesions ${ }^{(18)}$. It enables morphological evaluation of the surface, thickness, volume and subchondral bone (Figure 1). Arthroscopy - This is the gold standard examination for intra-articular pathological conditions of the $\mathrm{knee}^{(19)}$. Through using this tool, lesions can be classified, located and palpated (Figure 2).
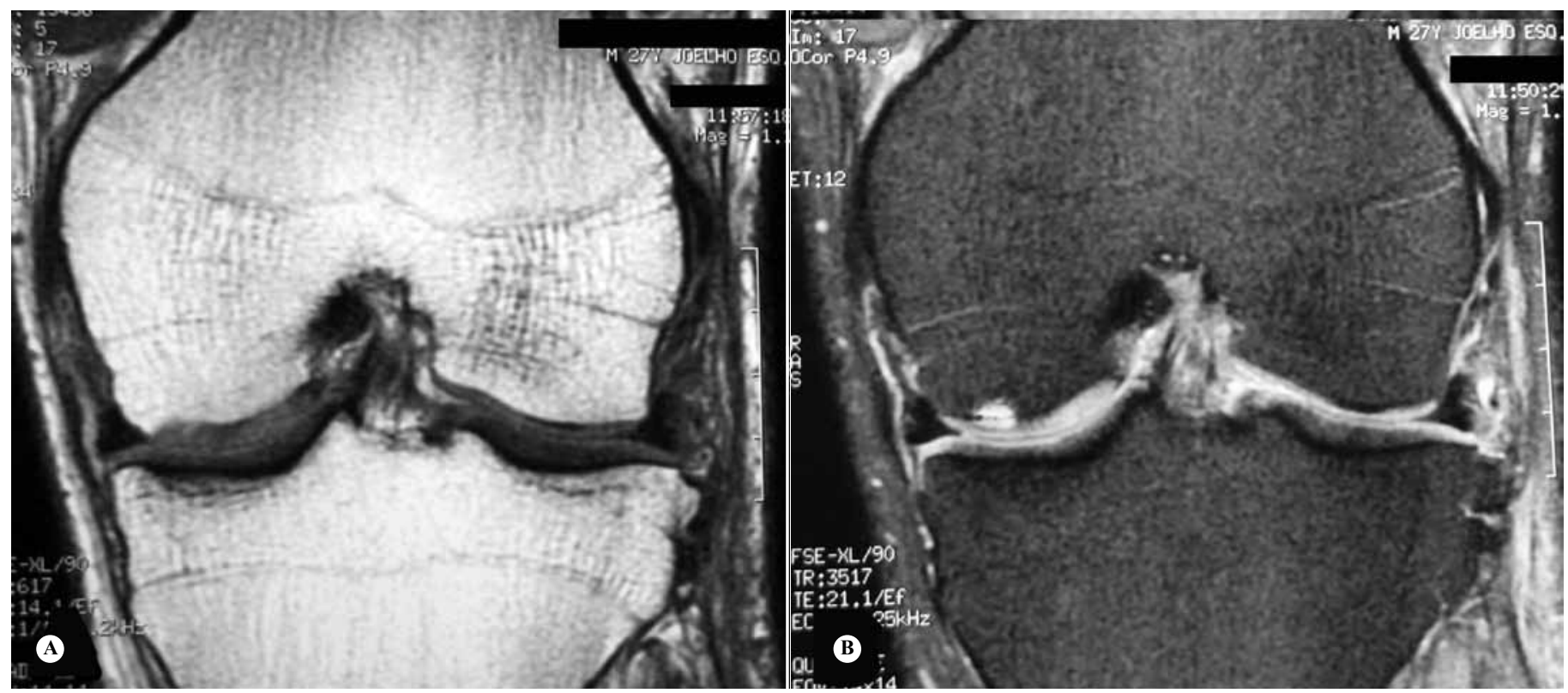

Figure 1 - NMR with T1 weighting (A) and T2 weighting $(B)$ on the patient of the radiographs in photo 1 (B and C), showing appearance of chondral lesion that was not seen on the radiographs. The lesion is seen better with T2 weighting.
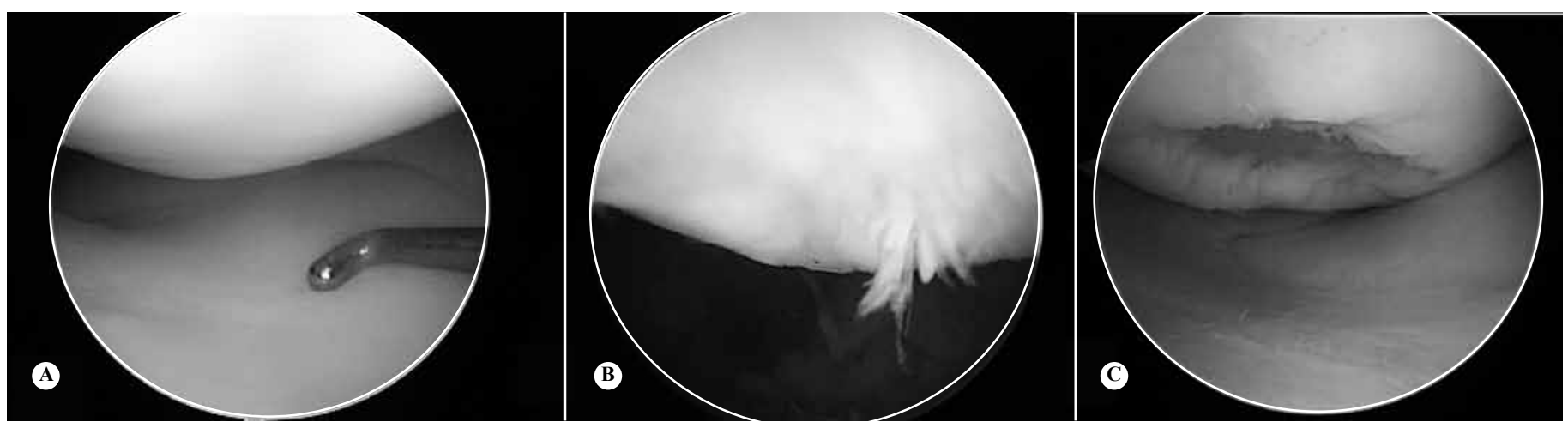

Figure 2 - Showing at letter A, cartilage without lesion; B, grade III chondral lesion; C, grade IV osteochondral lesion. 
a surface with more evenness ${ }^{(22)}$. Such procedures are performed arthroscopically, in order to minimize the pain and improve mobility, but they do not completely restore the cartilage structure and functions ${ }^{(23)}$.

\section{Debridement}

Debridement has commonly been used in treating osteoarthrosis, but it can also be used to treat purely chondral defects. The debridement procedure was established by Magnuson in 1941 apud Day ${ }^{(24)}$. The procedure used for partial chondral lesions involves removal of fragments such as unstable chondral flaps, osteophytes, excess synovium, degenerated menisci and torn ligaments ${ }^{(22)}$. It is generally done using a shaver, but other methods such as electrocautery, laser or radiofrequency techniques may also be used ${ }^{(25)}$. The aim of debridement is to eliminate symptoms, thus promoting pain relief and improved function. However, the symptoms can be expected to return ${ }^{(22)}$.

\section{Radiofrequency}

One alternative used for treating partial chondral lesions is radiofrequency, which has become very popular because this technique is easy to use arthroscopically and is effective for achieving an even surface across partial chondral lesions. However, the high intra-articular temperature associated with this method may have the potential to partially or completely destroy the joint cartilage ${ }^{(25)}$. Temperatures higher than $50^{\circ} \mathrm{C}$ have been defined as a critical threshold for chondrocyte death ${ }^{(26)}$. Occurences of necrosis associated with radiofrequency use depend on the quantity and duration of application of the energy ${ }^{(27)}$. The ideal technique for using radiofrequency devices is to use them like paintbrushes, in which they are kept in continual movement. Using this type of application, with two different types of radiofrequency, Amil et al ${ }^{(28)}$ demonstrated that chondrocytes remained intact and active at a depth of 100-200 $\mu \mathrm{m}$ below the treatment location. Over recent years, radiofrequency devices with temperature indicators have been developed, so that temperatures can be monitored during arthroscopy ${ }^{(29)}$.

Spahn et $\mathrm{al}^{(30)}$ conducted a prospective randomized controlled study to compare radiofrequency and mechanical debridement for treating chondral lesions of the knee. They concluded that all the patients were benefited by both treatments, although the patients treated with radiofrequency had results that were better than those of patients treated by means of mechanical debridement, over the first year of follow-up. The results were determined by means of a variety of scoring methods, such as the Tegner, visual analogue and KOOS scales.

\section{Total cartilage defects - osteochondral defects}

\section{Abrasion}

This is an arthroscopic technique for mechanical debridement using a motorized shaving device. It was first described as a palliative measure for attempting to avoid total knee arthroplasty in patients with osteoarthrosis. It is thought that stimulation of the subchondral bone may release mesenchymal cells from the bone marrow, thus promoting formation of new tissue ${ }^{(31)}$.

\section{Drilling}

This technique was developed by Pridie ${ }^{(32)}$, with the assumption that creation of a large number of holes in the subchondral plate would promote formation of fibrocartilage.

It is an arthroscopic technique that consists of stimulating the bone marrow through drilling holes in the bone, of diameter approximately $2.0-2.5 \mathrm{~mm}$, using a Kirschner wire. The clinical results did not differ from the findings using the abrasion technique ${ }^{(32)}$.

\section{Microfracture}

This is another arthroscopic technique for stimulating the bone marrow, by means of drilling holes in the bone, using specific tools with a tip in the shape of a sharp-pointed cone (Steadman Awl). This procedure was developed to regenerate the chondral defect. In microfractures, the osteochondral defect is firstly cautiously curetted to remove the remains of the calcified layer of the cartilage, and then the surface is evened out to produce a uniform defect. Following this, holes are drilled in the bone using the tool with the conical tip, starting at the edge of the lesion and going towards the center, leaving spaces of 3 to $5 \mathrm{~mm}$ between the holes. It is important to note that in the microfracture technique, the hole penetration is approximately $3 \mathrm{~mm}^{(33)}$. The intention with this technique is to promote formation of a coagulum of mesenchymal cells coming from the bone medulla, which will be responsible for forming a fibrocartilaginous repair ${ }^{(33)}$.

The clinical results from microfractures are largely dependent on the patient's age and the size of the cartilage defect. In young and active patients, microfrac- 
ture is recommended and has best long-term results in defects smaller than $2.5 \mathrm{~cm}^{2(34)}$. It has been reported that the microfracture procedure resulted in pain relief for $75 \%$ of the patients over long-term follow-up ${ }^{(34)}$. In contrast, other studies have demonstrated that the clinical improvement starts to diminish after around two years after the operation, especially among older patients ${ }^{(35)}$.

Because of the easy surgical technique, the low cost and the good results, microfracture has been widely used $^{(33)}$. The best indication is for defects smaller than $2 \mathrm{~cm}^{2}$, but improvements in symptoms may also be achieved in defects of up to $4 \mathrm{~cm}^{2}$. Better prognoses are found among young patients with defects in the femoral condyles. Less promising prognoses are found among patients with long-term lesions and high body mass index.

\section{Mosaicplasty}

Autologous osteochondral transplantation or mosaicplasty is a technique in which one or more osteochondral cylinders are removed from an area without offloading of weight for the area of the osteochondral defect (area with offloaded weight) ${ }^{(36)}$.

Mosaicplasty is an arthroscopic procedure that was first described by Hangody and Kárpati ${ }^{(37)}$. It consists of three stages ${ }^{(38)}$. The first stage is to prepare the receptor bed, which involves removing residual cartilage fragments from the chondral bed, down to the subchondral bone, followed by creation of cylindrical tunnels of depth $15 \mathrm{~mm}$, with a spacing distance of $1 \mathrm{~mm}$ between them. The diameter of the receptor bed should be $0.1 \mathrm{~mm}$ less than the diameter of the donor graft, such that it fits by being pressed in. The opening is constructed perpendicularly to the joint cartilage $^{(37)}$. The second stage is to harvest the graft, in cylindrical shape, with a length of $10-15 \mathrm{~mm}$. The final stage is to insert the osteochondral plug into the receptor location. It has been demonstrated that different sizes of graft ( 5.5 to $10 \mathrm{~mm}$ ) can be used in mosaicplasty ${ }^{(37)}$. The best scenario is the possibility of using a single cylinder that completely fills the osteochondral defect.

Mosaicplasty aims to make use of good bone-tobone healing in order to facilitate cartilage healing. The authors who conceived the technique suggested that it could be indicated for osteochondral defects of 1 to $4 \mathrm{~cm}^{2(39)}$. However, the bigger the defect is, the larger the area removed from the donor site has to be, which limits the possibility of indicating this technique for larger defects. Despite the good results shown by Hangody and Füles ${ }^{(36)}$ among patients over the age of 50 years, the success rate decreases significantly among older patients. Another limitation of this technique is that between the transferred osteochondral cylinders, there are empty areas without cartilaginous repair, which may cause morbidity at the donor site ${ }^{(40)}$.

Another issue that has been raised is the viability of chondrocytes from an area not subjected to loading that are transferred to an area with loading. At these locations, changes to the cartilage structure, loss of viability and subsequent degeneration of the joint cartilage are observed ${ }^{(41)}$.

The geometry of the cartilage in the osteochondral defect is not always the same as in the donor site. Achieving the ideal geometry for the affected region in cases of larger defects is a challenge for the surgeon, especially when the procedure is done arthroscopically ${ }^{(42)}$.

Gudas et al ${ }^{(43)}$ conducted a prospective study comparing mosaicplasty and microfracture among 70 patients. The patients were evaluated by means of the ICRS score, HSS score, arthroscopy, histology, nuclear magnetic resonance and radiography. They concluded that there were statistically significant improvements in the ICRS and HSS scores among the patients who underwent mosaicplasty, in relation to the microfracture group, 12 months after the surgical procedure. At the end of the follow-up, it was observed that there had been deterioration in the microfracture group (Figure 3).

\section{Allogenic osteochondral transplantation}

Allogenic osteochondral grafts from cadavers are also a treatment option for osteochondral defects. This is similar to the mosaicplasty technique, but is used on larger defects. It has the advantage that it can be done with a single osteochondral cylinder. The disadvantages of allogenic transplantation include immunological rejection, failure of bone incorporation and non-viability of the chondrocytes ${ }^{(44)}$.

McCulloch et al ${ }^{(45)}$ published a series of 25 cases of patients with osteochondral lesions who underwent allogenic osteochondral transplantation, with a twoyear follow-up. They found statistically significant improvements in the Lysholm, IKDC, KOOS and other scores; $84 \%$ of the patients were satisfied with the results and rated the functionality of the operated knee as $79 \%$, in relation to the non-operated knee. Radiographically, $88 \%$ of the grafts became fully incorporated into the receptor bone.

La Prade et $\mathrm{al}^{(46)}$ published a prospective study on 


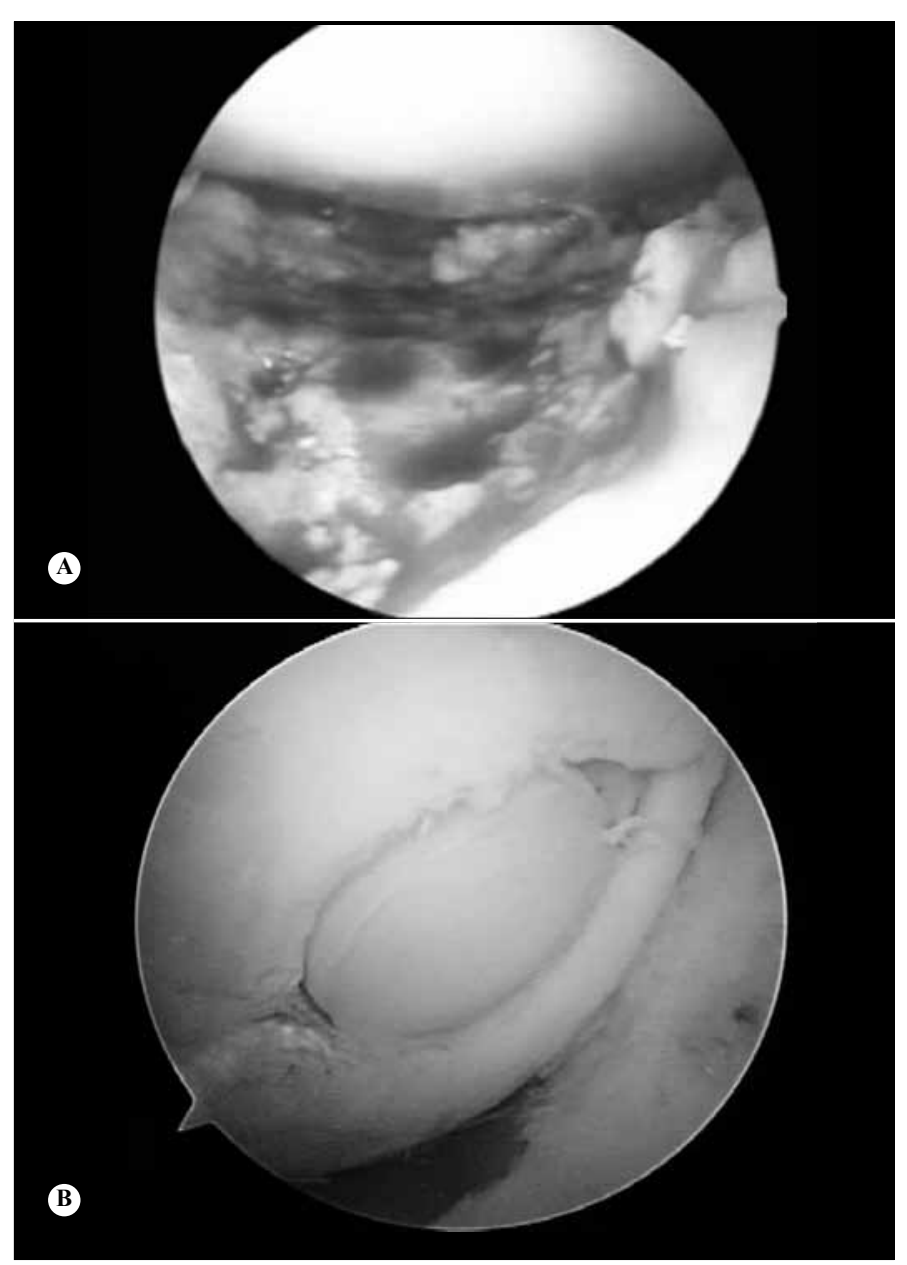

Figure 3 - (A) Microfracture in the region of the femoral trochlea; (B) Mosaicplasty on the medial femoral condyle.

23 patients with osteochondral lesions in the femoral condyle who underwent allogenic osteochondral transplantation, with a three-year follow-up. The patients were evaluated using the Cincinnati score before and after the operation, and the authors concluded that there was a significant improvement in this score. The allogenic osteochondral transplants, which had been stored under refrigeration for between 15 and 28 days, provided significant clinical and functional improvements after a mean follow-up of three years, and the results were similar to those from historical reports on fresh allogenic osteochondral grafts.

\section{Autologous chondrocyte transplantation: first generation}

Since 1994, when Brittberg et al ${ }^{(47)}$ published the first paper on implantation of chondrocytes for treating osteochondral defects, much has been developed in this area. Autologous chondrocyte transplantation to treat osteochondral defects is done as two surgical procedures. The first operation consists of cartilage bi- opsy from a healthy area, done arthroscopically. From this cartilage fragment, chondrocytes are cultured in the laboratory. After the number of cells has grown, a second, open surgical procedure is performed to implant these chondrocytes. The region of the defect is prepared, the edges are evened out and the chondrocytes are kept at the site by means of a layer of periosteum sutured to the borders of the lesion ${ }^{(47)}$.

The indications for autologous chondrocyte transplantation are lesions bigger than $2 \mathrm{~cm}^{2}$ and smaller than $12 \mathrm{~cm}$, and patients who continue to present pain after mosaicplasty or microfracture. The rates of good and excellent results have been $92 \%$ in single lesions, $67 \%$ in multiple lesions, $89 \%$ in osteochondritis dissecans, $65 \%$ in the patella and $75 \%$ in lesions associated with reconstruction of the anterior cruciate ligamentw. Factors that place limitations on widespread use of this surgical technique include the need for two surgical procedures, hypertrophy of the periosteal membrane (symptomatic in 13\% of the patients) and the high cost.

Knutsen et al ${ }^{(49)}$ published a study on 80 symptomatic patients with a single defect in the cartilage of the femoral condyle who were divided into two groups: 40 patients who underwent autologous chondrocyte transplantation and 40 who underwent microfracture. They were evaluated using the ICRS, Lysholm, SF-36 and Tegner scores, along with radiographic assessments using the Kellgren and Lawrence methods. It was concluded that after two to five years, both groups had achieved significant improvements, in comparison with their preoperative states. Both methods provided satisfactory results for $77 \%$ of the patients over a five-year period. There was no significant difference between the clinical and radiographic results, and there was no correlation between the histological findings and the clinical results. One third of the patients presented the first radiographic signs of osteoarthrosis five years after the surgery.

\section{Autologous chondrocyte transplantation: second and third generations}

The second generation of autologous chondrocyte transplantation has advantages over the first generation, given that there is no need to use periosteum. This avoids the need for an additional incision, which would be made to extract it, as well as avoiding possible hypertrophy of the periosteum.

Furthermore, second-generation autologous chondrocyte transplantation uses a matrix for culturing chondrocytes that has characteristics resembling those of the extracellular matrix of the cartilage. The matrixes available for use in Europe are: 1) MACI (Gen- 
zyme Biosurgery, Cambridge, MA, USA), which uses type I/III pig collagen and in which the chondrocytes are cultured three to four days before implantation; 2) Chondro-Gide (Geistlich Biomaterials, Switzerland), which is similar to MACI; 3) Hyalograft $\mathrm{C}$ (Fidia Advanced Biopolymers, Abano Terme, Italy), which is a three-dimensional matrix of hyaluronic acid that allows chondrocyte growth. The characteristics of these matrixes make it possible to perform the surgery arthroscopically, thus avoiding joint arthrotomy.

Saris et $\mathrm{al}^{(50,51)}$ published a randomized study comparing autologous chondrocyte transplantation using ChondroCelect (TiGenix NV, Leuven, Belgium) (57 patients) with microfracture (61 patients), with 36 months of follow-up. The results were evaluated using KOOS and nuclear magnetic resonance, and it was concluded that treatment of chondral lesions by means of autologous chondrocyte transplantation achieved a significantly better result over a 36-month period, compared with microfracture.

Basad et $\mathrm{al}^{(52)}$ published a randomized study comparing MACI autologous chondrocyte transplantation (40 patients) with microfracture (20 patients). The patients treated with MACI achieved a significant improvement in relation to those who underwent microfracture. The technique using MACI represents a significant advance in comparison with the first generation of autologous chondrocyte transplantation because of its surgical simplicity, safety and reproducibility.

\section{Use of stem cells in treating chondral lesions of the knee}

In 2007, Kuroda et al ${ }^{(53)}$ published a case report in which a 31-year-old judo player with an osteochondral lesion in the medial femoral condyle (classified as grade IV on the ICRS scale) was treated by means of using bone marrow cells. Arthroscopy performed seven months after the procedure found a defect covered with smooth tissue and histologically filled by hyaline cartilage tissue that stained positively with safranin-O. The symptoms were found to have improved significantly, one year after the surgery.

Wakitini et $\mathrm{al}^{(54)}$ published a study demonstrating the safety of autologous bone marrow cell transplantation for treating osteochondral defect, after 11 years and 5 months of follow-up. No occurrences of tumors or infections were observed during this follow-up, and the autologous bone marrow cell transplantation was considered to be a safe procedure. The stem cell transplantation was done either with a matrix or with a periosteal flap.

\section{One-step stem cell transplantation}

Giannini et $\mathrm{al}^{(55)}$ published the first paper on stem cell transplantation in a single procedure ("One-Step") for treating chondral lesions, which in this case were talar chondral lesions. In this procedure, bone marrow cells were aspirated and the material was centrifuged to separate red cells and plasma from the nuclear cells. Through this process, nuclear cells such as stem cells, monocytes, lymphocytes and other cells residing in the bone marrow can be obtained. Powdered collagen and a hyaluronic acid membrane were used as scaffolds for supporting the nuclear cells. In vitro preclinical tests were also performed in order to ascertain the capacity of the cells derived from bone marrow to differentiate into chondrogenic and osteogenic lineages. Forty-eight patients were evaluated with this technique, with a follow-up of two tears, and a significant improvement in functional scores was observed. The postoperative histological evaluation showed the presence of regenerated tissue at several stages of remodeling, although none of these patients subjected to histological examination presented fully hyaline cartilage.

Along these lines, Gobbi et $\mathrm{al}^{(56)}$ published the first case of stem cell transplantation using the onestep procedure to operate on a knee, with two years of follow-up. The procedure consisted of using bone marrow cells together with scaffolds of types I and III collagen. The patients presented significant improvements in all the scores evaluated, and tissue resembling hyaline cartilage was found in the histological tests. No adverse reaction or postoperative complications were found.

\section{Minced cartilage}

The principle of the minced cartilage technique is to achieve hyaline cartilage through chondral lesion repair using minced "fragments" of hyaline cartilage from an uninjured area that does not bear weight, often of autologous nature, complemented with a scaffold. A small quantity of minced cartilage creates sufficient chondrocytes to treat relatively large defects. Specifically, this technique requires only one tenth of the quantity of cartilage that originally filled the defect ${ }^{(57)}$.

The minced cartilage technique is attractive because it is performed as a single stage, using natural chondral tissue, and the minced cartilage can be 
applied using arthroscopic techniques. Studies on animals and preclinical models have demonstrated the presence of hyaline cartilage after the repair has been completed. Scaffolding and fibrin glue have been shown to be important for the viability of this technique. Additional clinical data and basic scientific data are needed on the minced cartilage technique ${ }^{(57)}$.

\section{Criteria for choosing the surgical technique}

Jones and Peterson ${ }^{(58)}$ recommended that for lesions of 1 to $2.5 \mathrm{~cm}^{2}$, microfracture is a good treatment option, as is mosaicplasty, provided that the graft is parallel to the joint surface. It is believed that microfractures can be used in less active patients, whereas in cases of patients who are more active, mosaicplasty may provide better cartilage repair. For lesions bigger than $2 \mathrm{~cm}^{2}$, autologous chondrocyte transplantation is the most indicated procedure ${ }^{(58)}$. For lesions bigger than $4 \mathrm{~cm}^{2}$, allogenic osteochondral transplantation is a good option ${ }^{(58)}$.

A systematic review conducted by Farr et $\mathrm{al}^{(59)}$, which included 77 articles, provided some recommendations and strategies for joint cartilage repair, in accordance with the current evidence (Table 2).

In a review on four randomized controlled studies, Bekkers et $\mathrm{al}^{(60)}$ concluded that the size of the lesions, the level of activity and age were the parameters that most influenced the result from joint cartilage repair surgery. Lesions larger than $2.5 \mathrm{~cm}^{2}$ should be

\section{REFERENCES}

1. Blackburn TA, Craig E. Knee anatomy: a brief review. Phys Ther 1980;60(12):1556-60

2. Ferretti M, Viola DCM, Garcia RJ. Tratamento dos defeitos osteocondrais. Einstein. 2009;7(2 Pt 1):245-7

3. Aigner T, Stöve J. Collagens--major component of the physiological cartilage matrix, major target of cartilage degeneration, major tool in cartilage repair. Adv Drug Deliv Rev. 2003;55(12):1569-93.

4. Rosowski M, Falb M, Tschirschmann M, Lauster R. Initiation of mesenchymal condensation in alginate hollow spheres--a useful model for understanding cartilage repair? Artif Organs. 2006;30(10):775-84.

5. Richmond JC. Surgery for osteoarthritis of the knee. Rheum Dis Clin North Am. 2008;34(3):815-25.

6. Bastiaansen-Jenniskens YM, Koevoet W, de Bart AC, van der Linden JC, Zuurmond AM, Weinans $\mathrm{H}$, et al. Contribution of collagen network features to functional properties of engineered cartilage. Osteoarthritis Cartilage. 2008;16(3):359-66.

7. Buckwalter JA. Articular cartilage: injuries and potential for healing. J Orthop Sports Phys Ther. 1998;28(4):192-202.

8. Prakash D, Learmonth D. Natural progression of osteo-chondral defect in the femoral condyle. Knee. 2002;9(1):7-10.

9. Outerbridge RE. The etiology of chondromalacia patellae. J Bone Joint Surg Br. 1961;43-B:752-7.

10. Brittberg M, Lindahl A, Nilsson A, Ohlsson C, Isaksson O, Peterson L. Treatment of deep cartilage defects in the knee with autologous chondrocyte transplantation. N Engl J Med. 1994;331(14):889-95
Table 2 - Strategies for good results from chondral lesions, according to Farr et al. ${ }^{(59)}$, treatment recommendations based on lesion size, according to Jones and Peterson ${ }^{(58)}$

\begin{tabular}{c|c|c|c}
\hline Technique & $\begin{array}{c}\text { Good results } \\
\text { Farr et al (59) }\end{array}$ & $\begin{array}{c}\text { Poor results } \\
\text { Farr et al (59) }\end{array}$ & $\begin{array}{c}\text { Lesion size } \\
\text { Jones and } \\
\text { Peterson (58) }\end{array}$ \\
\hline Microfracture & $\begin{array}{c}\text { Age }<40 \text { years } \\
\text { Focal lesion } \\
\text { Femoral condyle } \\
\text { Lesion }<4 \mathrm{~cm}^{2}\end{array}$ & $\begin{array}{c}\text { Age }>40 \text { years } \\
\text { Multiple lesions } \\
\text { Patellar lesion } \\
\text { Lesion }>4 \mathrm{~cm}^{2}\end{array}$ & $1-2.5 \mathrm{~cm}^{2}$ \\
\hline $\begin{array}{c}\text { Mosaicplasty } \\
\text { Allograft os- } \\
\text { teochondral }\end{array}$ & $\begin{array}{c}\text { Femoral lesion } \\
<2.5 \mathrm{~cm}^{2} \\
\text { transplantation } \\
\text { and chondral } \\
\text { loss Large dif- } \\
\text { fuse lesions }\end{array}$ & $\begin{array}{c}\text { Bipolar lesion } \\
\text { Lesion with bone } \\
\text { loss }\end{array}$ & $\begin{array}{c}\text { Bipolar lesion } \\
\text { Diffuse osteoar- } \\
\text { thritis }\end{array}$ \\
\hline $\begin{array}{c}\text { Chondrocyte } \\
\text { culturing }\end{array}$ & $\begin{array}{c}\text { Chondral lesion } \\
>2 \mathrm{~cm}^{2}\end{array}$ & $\begin{array}{c}\text { Extensive lesions } \\
\text { Bipolar lesion }\end{array}$ & $>2 \mathrm{~cm}^{2}$ \\
\hline
\end{tabular}

treated using sophisticated techniques such as autologous chondrocyte transplantation or autologous osteochondral transplantation, while microfracture is a good treatment option for lesions smaller than 2.5 $\mathrm{cm}^{2}$. Active patients present better results after autologous chondrocyte transplantation or autologous osteochondral transplantation than after microfracture. Younger patients $(<30$ years) seem to benefit more, independent of the type of cartilage repair surgery, than do patients over the age of 30 years.

11. Peterson L, Minas T, Brittberg M, Nilsson A, Sjögren-Jansson E, Lindahl A. Two- to 9-year outcome after autologous chondrocyte transplantation of the knee. Clin Orthop Relat Res. 2000;(374):212-34.

12. Brittberg M, Winalski CS. Evaluation of cartilage injuries and repair. J Boné Joint Surg Am. 2003;85(Suppl 2):58-69.

13. Curl WW, Krome J, Gordon ES, Rushing J, Smith BP, Poehling GG. Cartilage injuries: a review of 31,516 knee arthroscopies. Arthroscopy. 1997;13(4):456-60.

14. Widuchowski W, Widuchowski J, Trzaska T. Articular cartilage defects: study of 25,124 knee arthroscopies. Knee. 2007;14(3):177-82.

15. Conrad JM, Stanitski CL. Osteochondritis dissecans: Wilson's sign revisited. Am J Sports Med. 2003;31(5):777-8.

16. McCauley TR, Kornaat PR, Jee WH. Central osteophytes in the knee: prevalence and association with cartilage defects on MR imaging. AJR Am J Roentgenol. 2001;176(2):359-64.

17. Rand T, Brossmann J, Pedowitz R, Ahn JM, Haghigi P, Resnick D. Analysis of patellar cartilage. Comparison of conventional MR imaging and MR and CT arthrography in cadavers. Acta Radiol 2000;41(5):492-7.

18. Gold GE, McCauley TR, Gray ML, Disler DG. What's new in cartilage? Radiographics. 2003t;23(5):1227-42.

19. DeHaven KE, Collins HR. Diagnosis of internal derangements of the knee. The role of arthroscopy. J Bone Joint Surg Am. 1975;57(6):802-10.

20. Rosneck J, Higuera CA, Tadross N, Krebs V, Barsoum WK. Managing knee osteoarthritis before and after arthroplasty. Cleve Clin J Med. 2007;74(9):663-71.

21. Detterline AJ, Goldberg S, Bach BR Jr, Cole BJ. Treatment options for articular cartilage defects of the knee. Orthop Nurs. 2005;24(5):361-6. 
22. Li X, Shah A, Franklin P, Merolli R, Bradley J, Busconi B. Arthroscopic debridement of the osteoarthritic knee combined with hyaluronic acid (Orthovisc) treatment: a case series and review of the literature. J Orthop Surg Res. 2008;3:43.

23. Altman RD, Gray R. Diagnostic and therapeutic uses of the arthroscope in rheumatoid arthritis and osteoarthritis. Am J Med. 1983;75(4B):50-5.

24. Day B. The indications for arthroscopic debridement for osteoarthritis of the knee. Orthop Clin North Am. 2005;36(4):413-7.

25. Caffey S, McPherson E, Moore B, Hedman T, Vangsness CT Jr. Effects of radiofrequency energy on human articular cartilage: an analysis of 5 systems. Am J Sports Med. 2005;33(7):1035-9.

26. Mitchell ME, Kidd D, Lotto ML, Lorang DM, Dupree DM, Wright EJ, Lubowitz $\mathrm{JH}$. Determination of factors influencing tissue effect of thermal chondroplasty: an ex vivo investigation. Arthroscopy. 2006;22(4):351-5.

27. Edwards RB 3rd, Lu Y, Nho S, Cole BJ, Markel MD. Thermal chondroplasty of chondromalacic human cartilage. An ex vivo comparison of bipolar and monopolar radiofrequency devices. Am J Sports Med. 2002;30(1):90-7.

28. Amiel D, Ball ST, Tasto JP. Chondrocyte viability and metabolic activity after treatment of bovine articular cartilage with bipolar radiofrequency: an in vitro study. Arthroscopy. 2004;20(5):503-10.

29. Wienecke $H$, Lobenhoffer P. [Basic principles of radiosurgical systems and their applications in arthroscopy]. Unfallchirurg. 2003;106(1):2-12.

30. Spahn G, Kahl E, Mückley T, Hofmann GO, Klinger HM. Arthroscopic knee chondroplasty using a bipolar radiofrequency-based device compared to mechanical shaver: results of a prospective, randomized, controlled study. Knee Surg Sports Traumatol Arthrosc. 2008;16(6):565-73.

31. Nehrer S, Spector M, Minas T. Histologic analysis of tissue after failed cartilage repair procedures. Clin Orthop Relat Res. 1999;(365):149-62.

32. Pridie $\mathrm{K} \mathrm{H}$. A method of resurfacing osteoarthritic knee joints. J Bone Joint Surg Br 1959;41(3):618-9.

33. Mithoefer K, Steadman JR. The microfracture technique. Tech Knee Surg. 2006;5(3):140-8.

34. Nehrer S, Minas T. Treatment of articular cartilage defects. Invest Radiol. 2000;35(10):639-46.

35. Kessler MW, Ackerman G, Dines JS, Grande D. Emerging technologies and fourth generation issues in cartilage repair. Sports Med Arthrosc. 2008;16(4):246-54.

36. Hangody L, Füles P. Autologous osteochondral mosaicplasty for the treatment of full-thickness defects of weight-bearing joints: ten years of experimental and clinical experience. J Bone Joint Surg Am. 2003;85(Suppl 2):25-32.

37. Hangody L, Kárpáti Z. [New possibilities in the management of severe circumscribed cartilage damage in the knee]. Magy Traumatol Ortop Kezseb Plasztikai Seb. 1994;37(3):237-43.

38. Marcacci M, Kon E, Delcogliano M, Filardo G, Busacca M, Zaffagnini S. Arthroscopic autologous osteochondral grafting for cartilage defects of the knee: prospective study results at a minimum 7-year follow-up. Am J Sports Med. 2007;35(12):2014-21.

39. Gudas R, Stankevicius E, Monastyreckiene E, Pranys D, Kalesinskas RJ. Osteochondral autologous transplantation versus microfracture for the treatment of articular cartilage defects in the knee joint in athletes. Knee Surg Sports Traumatol Arthrosc. 2006;14(9):834-42.

40. Huntley JS, Bush PG, McBirnie JM, Simpson AH, Hall AC. Chondrocyte death associated with human femoral osteochondral harvest as performed for mosaicplasty. J Bone Joint Surg Am. 2005;87(2):351-60.

41. Whiteside RA, Jakob RP, Wyss UP, Mainil-Varlet P. Impact loading of articular cartilage during transplantation of osteochondral autograft. J Bone Joint Surg Br. 2005;87(9):1285-91. Erratum in: J Bone Joint Surg Br. 2005
42. Thaunat $M$, Beaufils $P$. The posterior femoral condyles: a potential donor site for mosaic-like osteochondral autograft? Arthroscopy. 2010 Nov;26(11):1503-9.

43. Gudas R, Kalesinskas RJ, Monastyreckiene E, Valanciūte A, Trumpickas V. [Osteochondral transplantation (mosaicplasty) in the treatment of knee joint cartilage defects]. Medicina (Kaunas). 2003;39(5):469-75.

44. Davidson PA, Rivenburgh DW, Dawson PE, Rozin R. Clinical, histologic, and radiographic outcomes of distal femoral resurfacing with hypothermically stored osteoarticular allografts. Am J Sports Med. 2007;35(7):1082-90.

45. McCulloch PC, Kang RW, Sobhy MH, Hayden JK, Cole BJ. Prospective evaluation of prolonged fresh osteochondral allograft transplantation of the femoral condyle: minimum 2-year follow-up. Am J Sports Med. 2007;35(3):411-20.

46. LaPrade RF, Botker J, Herzog M, Agel J. Refrigerated osteoarticular allografts to treat articular cartilage defects of the femoral condyles. A prospective outcomes study. J Bone Joint Surg Am. 2009;91(4):805-11.

47. Brittberg M, Lindahl A, Nilsson A, Ohlsson C, Isaksson O, Peterson L. Treatment of deep cartilage defects in the knee with autologous chondrocyte transplantation. N Engl J Med. 1994;331(14):889-95.

48. Peterson L, Minas T, Brittberg M, Nilsson A, Sjögren-Jansson E, Lindahl A. Two- to 9-year outcome after autologous chondrocyte transplantation of the knee. Clin Orthop Relat Res. 2000;(374):212-34.

49. Knutsen G, Drogset JO, Engebretsen L, Grøntvedt T, Isaksen V, Ludvigsen TC, et al. A randomized trial comparing autologous chondrocyte implantation with microfracture. Findings at five years. J Bone Joint Surg Am. 2007;89(10):2105-12.

50. Saris DB, Vanlauwe J, Victor J, Almqvist KF, Verdonk R, Bellemans J, et al. Study Group. Treatment of symptomatic cartilage defects of the knee: characterized chondrocyte implantation results in better clinical outcome at 36 months in a randomized trial compared to microfracture. Am J Sports Med. 2009;37(Suppl 1):10S-19S.

51. Saris DB, Vanlauwe J, Victor J, Haspl M, Bohnsack M, Fortems Y, et al. Characterized chondrocyte implantation results in better structural repair when treating symptomatic cartilage defects of the knee in a randomized controlled trial versus microfracture. Am J Sports Med. 2008;36(2):235-46.

52. Basad E, Ishaque B, Bachmann G, Stürz H, Steinmeyer J. Matrix-induced autologous chondrocyte implantation versus microfracture in the treatment of cartilage defects of the knee: a 2-year randomised study. Knee Surg Sports Traumatol Arthrosc. 2010;18(4):519-27.

53. Kuroda R, Ishida K, Matsumoto T, Akisue T, Fujioka H, Mizuno K, et al. Treatment of a full-thickness articular cartilage defect in the femoral condyle of an athlete with autologous bone-marrow stromal cells. Osteoarthritis Cartilage. 2007;15(2):226-31.

54. Wakitani S, Okabe T, Horibe S, Mitsuoka T, Saito M, Koyama T, et al. Safety of autologous bone marrow-derived mesenchymal stem cell transplantation for cartilage repair in 41 patients with 45 joints followed for up to 11 years and 5 months. J Tissue Eng Regen Med. 2011;5(2):146-50..

55. Giannini S, Buda R, Vannini F, Cavallo M, Grigolo B. One-step bone marrowderived cell transplantation in talar osteochondral lesions. Clin Orthop Relat Res. 2009;467(12):3307-20.

56. Gobbi A, Karnatzikos G, Scotti C, Mahajan V, Mazzucco L, Grilogo B. One-Step Cartilage Repair with Bone Marrow Aspirate Concentrated Cells and Collagen Matrix in Full-Thickness Knee Cartilage Lesions: Results at 2-Year Follow-up. Cartilage. 2011;38(2)95:104.

57. McCormick F, Yanke A, Provencher MT, Cole BJ. Minced articular cartilage-basic science, surgical technique, and clinical application. Sports Med Arthrosc. 2008;16(4):217-20.

58. Jones DG, Peterson L. Autologous chondrocyte implantation. J Bone Joint Surg Am. 2006;88(11):2502-20.

59. Farr J, Cole B, Dhawan A, Kercher J, Sherman S. Cartilage restoration: evolution and Overview. Clin Ortho Relat Res. 2011;469(10):2696-705.

60. Bekkers JE, Inklaar M, Saris DB. Treatment selection in articular cartilagelesions of the knee: a systematic review. Am J Sports Med. 2009;37(Suppl 1):148S-55S.

\section{ERRATA}

In volume 46, issue no. 6, of the journal RBO (November/December), in the article "Scheuermann's Kyphosis: comparison between the posterior approach associated with Smith-Petersen osteotomy and combined anterior-posterior fusion", on page 709, where it reads: dufrois@gotimail.com, the correct address is dufrois@hotmail.com.

Furthermore, in the titles and affiliations of the author Luiz Olimpio Garcia Pedrosa, where it reads: "Third-year Resident Physician of Orthopedics and Traumatology of Professor Matta Machado's Service at Hospital da Baleia/Benjamin Guimarães Foundation, Belo Horizonte, MG, Brazil", the correct title is "Coordinator of the Spine Group of Professor Matta Machado's Service at Hospital da Baleia/Benjamin Guimarães Foundation, Belo Horizonte, MG, Brazil. 